\title{
競争場面における運動パフォーマンス に及ほす達成動機づけの影響
}

西田保 (筑波大学)

（昭和52年 7 月19日 受付）

\section{Effects of Achievement Motivation on Motor Performance in Competitive Conditions}

\author{
Tamotsu Nishida*
}

\begin{abstract}
The purpose of the present investigation was to examine the effects of achievement motivation on motor performance in competitive conditions. The hypotheses were derived from Atkinson's Expectancy-Value Model and Yerkes-Dodson's Law.

There were 76 achieve success subjects ( $T_{8}$ group) and 76 avoid failure subjects ( $T_{F}$ group), chosen from 421 fifth grade boys on the basis of their scores on the McClelland's Thematic Apperception Test and the Sarason's Test Anxiety Scale for Children. Initially, each group was tested in the zigzag run task and the serial jumping task under the control condition, and then placed into one of the four competitive conditions. The four competitive conditions were competition with inferior, equal and superior ability opponents, and noncompetition. The subjective probability of success expected for the first three conditions was $0.75,0.50,0.25$, respectively. Each group was given the same motor task under these competitive conditions. Performance changes from control condition to competitive conditions were analyzed by two-factor analysis of covariance ( 2 achievement motivation $\times 4$ competitive conditions).

The main results obtained were as follows:

(1) In the zigzag run task, both the $T s$ group and the $T_{F}$ group increased their competitive performances, with the $T_{\mathbf{s}}$ group showing a higher increase in performance under competition with equal ability opponents than under competition with inferior and superior opponents.

(2) In the serial jumping task, the $\mathrm{T}_{\mathbf{8}}$ group did not increase their competitive performances, but the $T_{F}$ group showed a greater decrease in performance under competition with equal ability opponents than under competition with inferior and superior opponents.

It would appear that a knowledge of motivations both to achieve success or to avoid failure would enhance the possibility of predicting success in competitive situations.

(Tamotsu Nishida : Effects of Achievement Motivation on Motor Performance in Competitive Conditions. Jap. J. Phys. Educ., Vol. 23, No. 1, June, 1978, pp. 13 23)
\end{abstract}




\section{[1]間医}

体育・スポーツ場面では，運動パフォーマソス を向上させるための手段として，競争を意図的に 導入与ることが多い。これは，共通の目標に対し て，尔互いが他人ょり優れた成績を得よ 5 と努力 する優越および達成の要求を有効に利用しよ5と したものである。

そこで，競争と運動パフォーマンスの関係を調 ベてみると，競争によってパフォーマンスが向上 したり，低下したり，あるいは変化がみられない など，一貫した結果が得られていない。このこと は，競争場面では多くの要因が複雑にからみあっ ており，一義的就解釈の困難性を示唆するもので ある・

しかしながら，体有・スポーツ場面でよくみか ける現象であるが，相手に勝と5と積極的に努力 している人もいれば，負けるのではないか失敀す るのではないかと，とまどいながら競争に参加し ている人もいる。つまり，競争場面では，目標や 卓越基準に対して接近しょ5とする達成動機と， 失敗を恐れてそれらから回避しょうとする失敗回 避動機が複雑に錯綜し，ある種の葛藤状態を作り 出していると考光られる．さらに，競争場面が， ある基準や価值感を媒介に，相手よりる「勝ちた い」「負けたくない」とい5優越および達成の要 求に結びついた動機 つけ場面であると考えるなら ば，競争による運動バフォーマンスに，達成動 機，失敗回避動機が大きく影響を及ぼしていると 考えられる。

そこで，競争と達成動機および失敗回避動機に 関する従来の研究を調べてみると，E．D. Ryan, and W. L. Lakie, (1965'1)) は, 男子大学生を対 象に，知筧運動課題を用いた結果，高達成動機群 （高達成動機一低テスト不安群）は競争条件でパ フォーマンスが優れ，一方，低達成動機群（低達 成動機一高テスト不安群）は高達成動 機群より も，非競争条件でバフォーマンスが優れていたと 報告している・また，男子大学生を対象に円盤突 き課題を用いた G. C. Roberts，(1972 $\left.{ }^{18)}\right)$ や， 高校生男子を対象に平衡安定保持課題を用いた T. R. Healey, and D. M. Landers, $\left(1973^{10)}\right)$ の 研究では，達成動機，競争条件およびそれらの交
互作用に有意差がみられなかったものの，試行の 最初の段階で競争を埕入した時には，高達成動機 群の方が低䢖成掰機群よりるパフォーマンスが優 れていたと報告している。これらのことから、一 般的に; 高達成動機群は低達成動機群よりも, 競 争によって運動パフォーマンスがより促進される であろうといら予想が立つ.

しかしながら、これらの研究は単に競争条件を 設定しただけであって，どのような競争条件であ ったのかが明確にされていない，競争場面は，多 くの場合，自己と競争相手 との比較をある基隼と 価值感を持って評価している場面であり，そこに は認知的な変数が関与していると思われる。つま り，競争相手に対する勝敗の主観的な認知によっ て動機つけ水集が変化し，運動パフォーマンスに 影慗を及ぼすと考えられる，また，これらの主観 的な勝敗の認知は，体育・スポーツ場面での過珡張 やあがりなどとも深い関連性があると思われる。

このよ5な達成志向場面に打ける目標達成への 主観的確事と動機のけと関係について，J.W. Atkinson, (19572)）は，「期待一誘因価モデル」 として，次のよ5に公式化した。

合成された達成志向傾向

(Resultant Achievement Motivation) =

$$
f\{(\mathrm{Ms}-\mathrm{Maf}) \times \mathrm{Ps} \times \mathrm{Is}\}
$$

ここで，Ms は達成動機，Maf は失敗回避勤機 で，Psはその行動を遂行することにより目標を達 成するであろ5期待（主観的成功確事）であり， Is はその目標の語因価である．このモデルの特徽 は，Is=1-Ps と仮定したところにあり，このこ とから, R.A.M. の強さは, Ps が中程度 (Ps = .50）である時には，より高い(Ps>.50) とか， より低い $(\mathrm{Ps}<.50)$ 時よりも强くなるが，Ms が Maf よりる大きい場合 (Ms>Maf) には，行動と して接近の方向を示し，逆の場合 (Ms $<\mathrm{Maf})$ に は，回避の方向を示すと考えられている，そし て，このモデルに関する研究は，パフォーマン ス，要求水準，持続性などについて実験的に検 泟された. (E. G. French, and F. H. Thomas, 19589). J. W. Atkinson, et al. 19604). J. W. Atkinson, and G. H. Litwin, 19605). N. T. 
Feather, 1965 ${ }^{8}$. J.O. Raynor, and C.P. Smith, $1966^{16)}$. S. A. Karabenick, and Z. I. Youssef, 1968'2). J. O. Raynor, and I. S. Rubin, 1971'17). G.C. Roberts, 1974(19).) これらの実験的検討は, 中性的場面上りも，何らかの卓越基暲に従って努 力したり, 成功や失敗（勝・敗）が自分の能力ゃ 努力によって導びかれるという達成志问場面で支 持されたものが多いことから，このモデルの競争 場面との関連性性非常に大きいであろう。

そこで，競争と競争相手の能力水望に関する従 来の研究を調べてみると，長田 (196915) $)$ は高校 生を対象に腕立伏臥腕届伸運動を行なった結果, 単独条件中異質能力者間の競争よりる, 同質能力 者間の競争の方が，運動パフォーマンスがより促 進されたと報告している。また，C. H. Strong， (196324)）の筋力・スピード・持久力をみる体力 テストや，右高 (196925) の50m 走の研究 向同 様の䊅果を示している.これらの結果は，J. W. Atkinson の「期待一誘因価モデル」が示すよ 5 に，主観的成功確率が中程度であると考党られる 同質能力者間の競争で動機づけが最大になるとい 5前提にたっている.ところが，前述したよう に, 高達成動機群 と低達成動機群とでは, 課題に 対する動機つけの方向が異なるため，パフォーマ ンスとしてす逆の方向を示すと考えられる・従っ て，高達成動機群は，自己と競争相手の能力が同 等であると証知した場合，すなわち主観的成功確 率がほぼ50パーセントの時に，達成への動機づけ が最大になりパフォーマンスが促進されるのに対 して，低達成動機群は，そのよ5な場合には失敗 回避への動機づけが最大になり，パフォーマンス が抑制されるであろうと考えられる。

一方，動機つけとの関連から運動パフォーマン スを考えると，主としてスピードや筋力を必要と する運動課題では，競争によってパフォーマン スが促進される (R. M. Church, 19627). C. H.

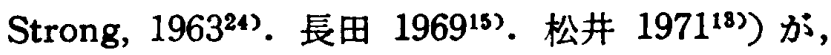
鋭敏な知觉判断や協応性を必要とする運動課題で は，逆に抑制される傾向がある (M. E. Shaw, 195823). E. Rudow and Hautaluoma, 197520)). また, J. W. Atkinson, and W. R. Reitman, $\left(1956^{1)}\right)$ p J.W. Atkinson, and P.O'Connor, $\left(1966^{8)}\right)$ の研究で，動機つけの强さとパフォーマ ンスとの間に，単調な增加関係がみられなかった ことから，競争の効果は課題によっても異なって くると考えられる・これに関して，動機つけの強 さとパフォーマンスとの間には逆U字型の関係が 存在し, 課題が単純で容易になるほどその課題に 対する動機つけの最適水隼は高くなり，課題が複 雑で困難になるほど動機 つけの最適水算は低くな るという Yerkes-Dodson の法則が多くの示唆を 提供している。また，動機つけとパフォーマンス に関する従来の研究を調へてみると，前者の課題 は主としてスピードや筋力を必要とする課題と， 後者の課題は主として 鋭敏な知堂判断や協応性を 必要とする課題とほほ対応しているょ5である。 このことから，主としてスピードや筋力を必要と する運動課題では，より高い動機つけ水策でパフ オーマンスが促進されるのに対して，主として鋭 敏な知覚判断や協応性を必要とする運動課題で は，より低い䡃機づけ水篗でパフォーマンスが促 進されるであろうと考学られる。

\section{[2] 目的}

そこで本研究は，競争が運動パフォーマンスに 大きな影翠を及ぼしている要因として，達成動機 および失敗回避勘機と競争相手に対する勝敗の主 稓的な認知を取りあげ，J. W. Atkinson の「期 待一誘因価モデル」と Yerkes-Dodson の法則か ら，次の仮説を立てそれらを検証する目的で行な われた。

\section{(仮説)}

主としてスピードや筋力を必要とする運動課題 では，より高い動機づけ水漸でパフォーマンスが 促進されることから，

1. 高達成功機群 ( $\mathrm{T}_{\mathrm{B}}$ 群)，低達成動機群 ( $\mathrm{T}_{\mathrm{F}}$ 群）とも，非競争条件よりあ競争条件でパフォー マンスが促進されるであろう．また，動機つけけ が最も強くなる勝敗の主観的確率が中程度 (Ps= .50)の条件において, パフォーマンスが著しく促 進されるであろ5。

2. Ts群は, 課題に対して接近の方向を示す行 動特性を持つため， T君群よりも競争によってパフ オーマンスがり促進されるであろ5。

主として鋭敏な知觉判断や協応性を必要とする 
军動課題では，より低い功機づけ水䇤でパフォー マンスが促進されることから。

3. T群, T群とも非競争条件よりる競争条件 でパフォーマンスが㧕制されるであろう．また，

功機つけが最る强くなる勝敗の主钼的確事が中程 度 (Ps=.50) の条件において，パフォーマンス が著しく㧕制されるであろう。

4. T群は, 課題に対して回群の方向を示す行 動特性を持つため， $T_{8}$ 群よりす競争によってパフ オーマンスがより抑制されるであろ5。

\section{[3] 万法}

\section{$<1>$ 被験者}

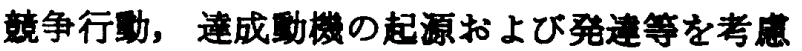
して，それらが比較的影著にあらわれる小学校 5 年生男子 421 名を対象に，次の 2 種の動機を测定 した。

（1）達成動機（Ms）の测定

D. C. McClelland 5 (195314) Kよる「主題 統賞検查— Thematic Apperception Test (T. A. T.)」を，中性的条件下で学級単位で実施 した、各想像物語の内容の分析は，彼等の方法注 1) に従って行ない, AI (Achievement Imagery), TI (Doubtful Imagery), UI (Unrelated Imagery）と判定した。つまり，AIは，達成動機に関 する記述が明確である場合の判定基隼であり，TI は，達成しょ5とする記述はみられるが，AIほど 明確でない場合，UIは，達成動機とは無関係な 記述がしてある場合に判定した。そして，AIには 2 点, TI には 1 点, UI には 0 点を重みつけ， 4 四版それそれれの合計得点を達成動機得点とした。

（2）失敗回避䵢機（Maf）の測定

D. C. McClelland 5 (195314) $)$ Ð, J. W. Atkinson (1958') $)$ は，失敗回避动機を，達成志 向場面やテスト類似場面で生じる不安動機と考古 ている. そこで， S. B. Sarason ら (196022) $)$ 「児童用テスト不安尺度—Test Anxiety Scale for Children (T.A.S.C.)」を用い，中性的条件 下で学級単位で実施した３0項目からなる筫問は 㭘查者がロ頭で示し，その合計得点を失敗回避動 機得点とした。

以上の測定の後，各得点をそれそれ標注得点に 换算し, 達成功機得点から失敗回避動機得点を引
き，その差の上位20パーセント，下位 20パーセン トの者を選択し，それそれ高達成動機群 ( $\mathrm{T}_{\mathrm{8}}$ 群一 $\mathrm{Ms}>\mathrm{Maf}$ 群, 76名), 低達成動機群 ( $\mathrm{T}_{\mathbf{F}}$ 群一 $\mathrm{Ms}_{\mathbf{8}}$ （Maf群, 76名）とした。

\section{$<2>$ 実踽期間 1976年 9 月～11月 \\ $<3>$ 连動課題 \\ (1) ジグザグラン}

Fig. 1 のような実験場面（体有館）を設定し， 矢印の方向（逆の方向でもよい）に走りながらポ 一ルを通過し，折返し点でボールを持ってスター ト地点にもどることを要求した。ポールの高さは 䄪 $150 \mathrm{~cm}$ であり，ボールはドッヂボール 2 号を用 いた。なお，折返し点では，ボールを固定させる ために直径 $40 \mathrm{~cm}$ の岟を用い，ボールをその中に セットした。この課題は，主としてスピードを必 要とするもので，予備実験の結果，競争を導入す ることによってパフォーマンスが促進されるるの であった・（p<.01）また，この課題の再テスト 法による信頼性係数は，0.85であった。

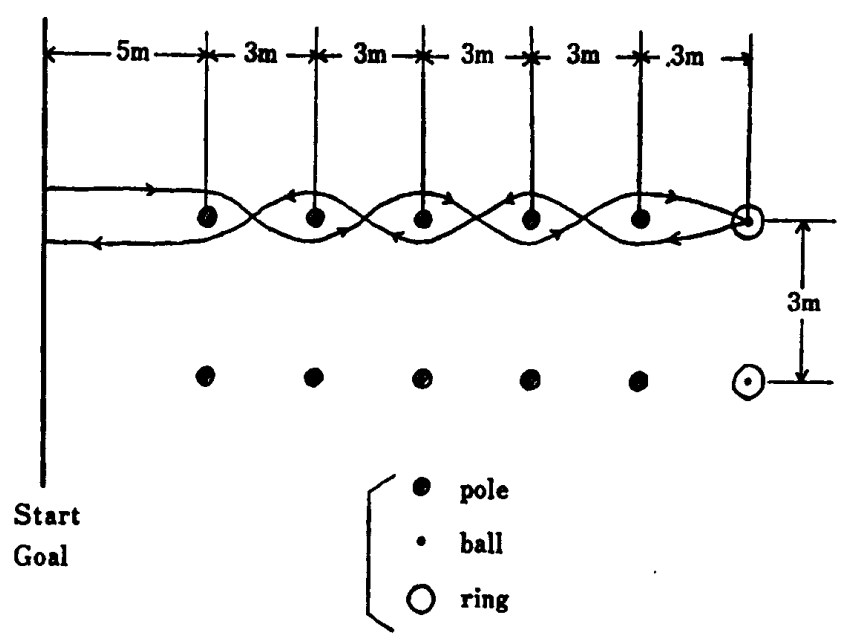

Fig. 1. Floor diagram of the zigzag run task

(2) ケンケンとび

Fig. 2 のよ5にランダムに設定した赤，白，青 色の直径 $40 \mathrm{~cm}$ の輪を, 赤色は右足, 白色は両足, 青色は左足でジグザグに連続してとふことを要求 した.この課題は，3つの色刺激を弁別しなが ら，それに対态した䡃作を行な5とい5協応性課 題であり，予備実験の結果，競争を導入すること によってパフォーマンスが㧕制されるすのであっ た.（p<．05）また，再テスト法による信頼性係 


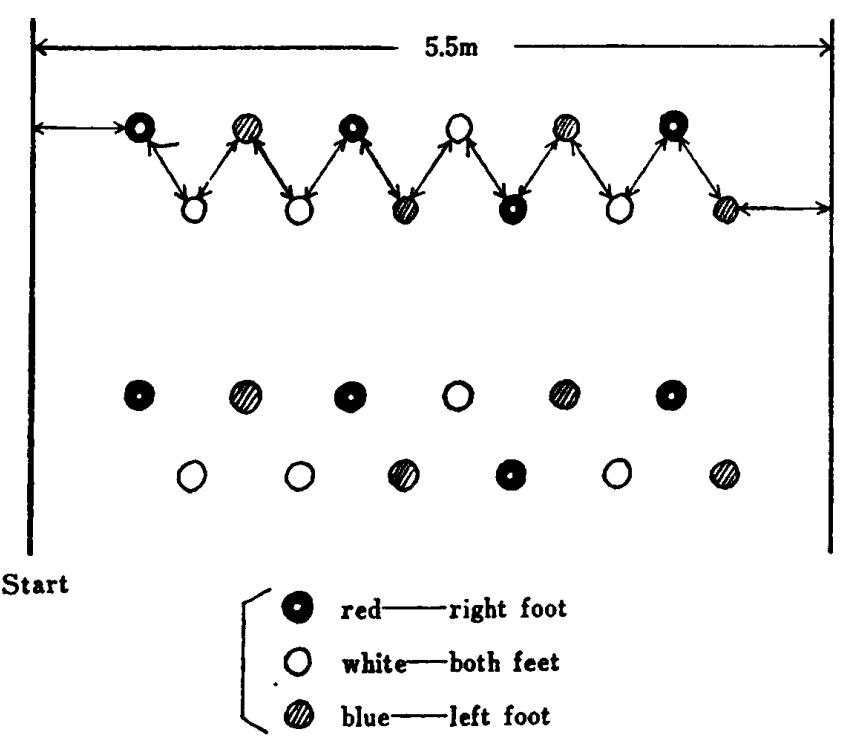

Fig. 2. Floor diagram of the serial jumping task

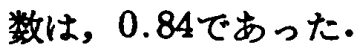

\section{<4> 実験条件および手続き}

ジグザグラン，ケンケンとび両課題を，全被 験者（421名）に，実験者之被験者の 2 人きりの 中性的場面で 2 回実施し, それらの平均值を統制 条件での個人の成績とした. その後, 統制条件で の成樍から個人のパーセンタイル順位 (P.R) を 求め, $T_{8}$ 群， $T_{\mathrm{F}}$ 群を競争 相手 とのP.Rの差が, (1) +20 以上の条件（勝敗の主観的確率か; 0.75 く らいと期待できる条件として， $\mathrm{C}_{75}$ 条件と命名し た）・（2） \pm 5 以内の条件（同様に $\mathrm{C}_{50}$ 条件と命名 した). (3) -20 以上の条件 (同様に $\mathrm{C}_{25}$ 条件と命 名した).（4）非競争条件 (N.C 条件) という競 争条件にランダムに割り当てた。（Tab. 1) その
結果, ジグザグランでは，各群間に有意差がみら れず，全群が等質であることが認められたま た,ケンケンとびにおいても，T $\mathrm{T}$ 群の 4 群間, $\mathrm{T}_{\mathrm{F}}$ 群の 4 群間に有意差はみられなかった。ここ で, P.R を求めたのは，小学生が競争する場 合 に，成績を示すよりも相対的な順位を示す方が， 競争相手を把握するのにより適切であると考えた からである・また，競争条件をこのように分類し たのは，競争相手と明らかに能力差があること を，被験者が意識できることを考㦄してのことで ある.

その後, 両群ともそれぞれの競争条件で, ジグ ザグラン，ケンケンとび両課題をカウンターバラ ンスして2試行行なったその際にこのように 設定した競争条件に対して，被験者が実験者の意 四する競争条件で課題を遂行していたのかどうか を検討するために，試行の前に，競争相手に対す る勝敗の主観的判断を 5 段階の評定尺度 (1. 絶 対負けるだろ5．2. 多分負けるたろ5．3.勝てる か負けるかわからない４．多分勝てるたろう。

5. 絶対勝てるたろう.) で求めた。なお，両課題

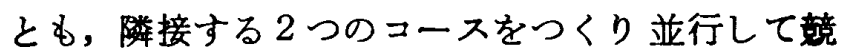
争させ，コースを変えることによって位置の効果 を相殺した。また，N，C 条件においては，C 75 , $\mathrm{C}_{50}, \mathrm{C}_{25}$ 条件で統制条件での成精を知らせている ことから，K.Rの効果を統制する意味でここです それを知らせたが，その他は統制条件と全く同じ 要領で行なった。

\section{$<5>$ 結果の処理}

Tab. 1 Mean performances and standard deviation under control condition

(points)

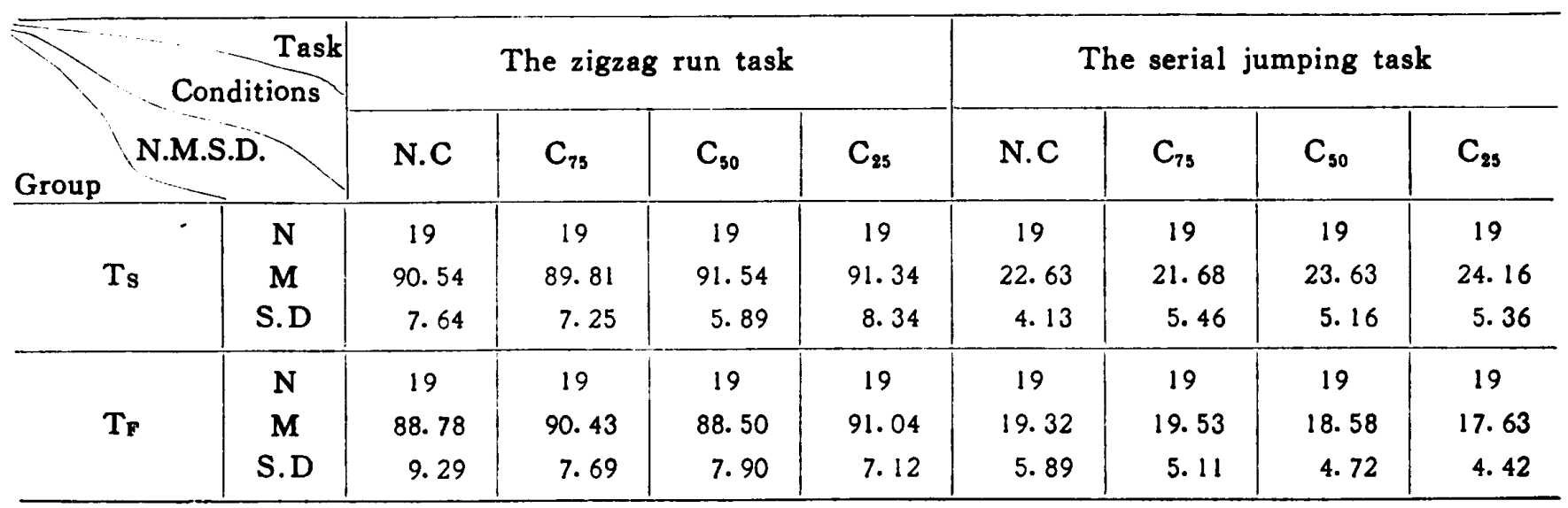


ジグザグランは， $1 / 10$ 秒まで測定した所要時間 を逆数変換して1000倍したすのを，ケンケンとび は，20秒間で正確にとんだ数（20秒間で進んだ数 一㕵数）を得点とした。その後，両課題におい て，それそれ達成野機（2）×競争条件（4）の 2 要 因共分散分析を行なった。

\section{[4]模果}

\section{$<1\rangle$ 予備的検討に関する結果}

（1） T.A.T., T.A.S.C. 得点の信頼性

予備実験での T.A.T., T.A.S.C. 得点の信頼性 係数は，Table. 2 に示すとおりで，かなり信頼性 の高い測度であることが認められた。

Tab. 2 Reliability coefficients of T.A.T and T.A.S.C scores

\begin{tabular}{c|c|c|c}
\cline { 2 - 4 } & T.A.T & \multicolumn{2}{|c}{ T.A.S.C } \\
\hline Method & $\begin{array}{c}\text { test-retest } \\
\left(\begin{array}{l}\text { over a } \\
\text { 4-week } \\
\text { interval }\end{array}\right)\end{array}$ & $\begin{array}{c}\text { test-retest } \\
\text { over a } \\
\text { 4-week } \\
\text { interval }\end{array}$ & $\begin{array}{c}\text { Split- } \\
\text { half }\end{array}$ \\
\hline $\begin{array}{c}\text { Reliability } \\
\text { coefficients }\end{array}$ & $0.700^{* * *}$ & $0.753^{* * *}$ & $0.861^{* * *}$ \\
\hline Subjects & 102 & 104 & 223 \\
\hline
\end{tabular}

$* * * \mathrm{P}<.001$

（2） T. A. T. 得点の評定者間注 2)の一致事注 3) および相関

AI，TI，UI の評定者間の一致种は，それぞれ 87.9，77.5，95.1 パーセントであり，かなり高い 一致率がみられた。また，T.A.T. 得点の評定者 間の相関係数は，0.922（p<.001）で，かなり高 い相関がみられ, 本研究の T.A.T. 得点は, 相互 の主観性が高いものであると考えられる。

\section{（3）達成现機之競争との関係}

競争を導入することによって達成野機が喚起さ れるのかどうか，また，競争による運動パフォ一 マンスの向上が，強い達成動機の喚起によるすの かどらかを調べるために，小学校 5 年生男子 46 名 を対象に, T.A.T., T.A.S.C. ジグザグラン，ヶン ケンとびを，非競争条件と競争条件で実施した。 その結果，T.A.T., T.A.S.C. 得点とも両条件間 に有意な差はみられなかったが，どちらす競争条 件で高い得点を示す傾向がみられた．（p<.10） また, T.A.T., T.A.S.C. 得点の変化量（競争条件
一非競争条件）と，ジグザグラン，ケンケンとび 得点の変化量との相関を求めたところ，T. A. T. 得点とジグザグラン得点の変化量に有意な正の相 関 $(r=0.51, p<.001)$, T.A.S.C. 得点とケンヶ ンとび得点の変化量に有意な負の相関 $(r=-$ $0.37 ， \mathrm{p}<.05 ）$ が得られた。

以上の結果から，競争による運動パフォーマン スに達成動機, 失敗回避動機が関与していること が認められ，競争を導入することによってそれら が喚起され，運動パフォーマンスに影製を及ぼし たと考えられる。

（4）競争相手に対する勝敗の主䧽的評定点と 競争条件との関係

本研究における競争条件は，個人の統制条件で の得点をもとに，実験者が操作的に設定したすの である・そこで，被験者が実験者の意図する競争 条件で課題を遂行していたのかどうかを検討し た. 各々の課題に甜ける勝敗の主観的評定点の平 均值は，Fig. 3，4，に示すとおりで，両課題とも 各競争条件間に有意差 $(\mathrm{p}<.01)$ がみられたが， $\mathrm{T}_{\mathrm{s}}$ 群，T群間には有意差はみられなかった。ま

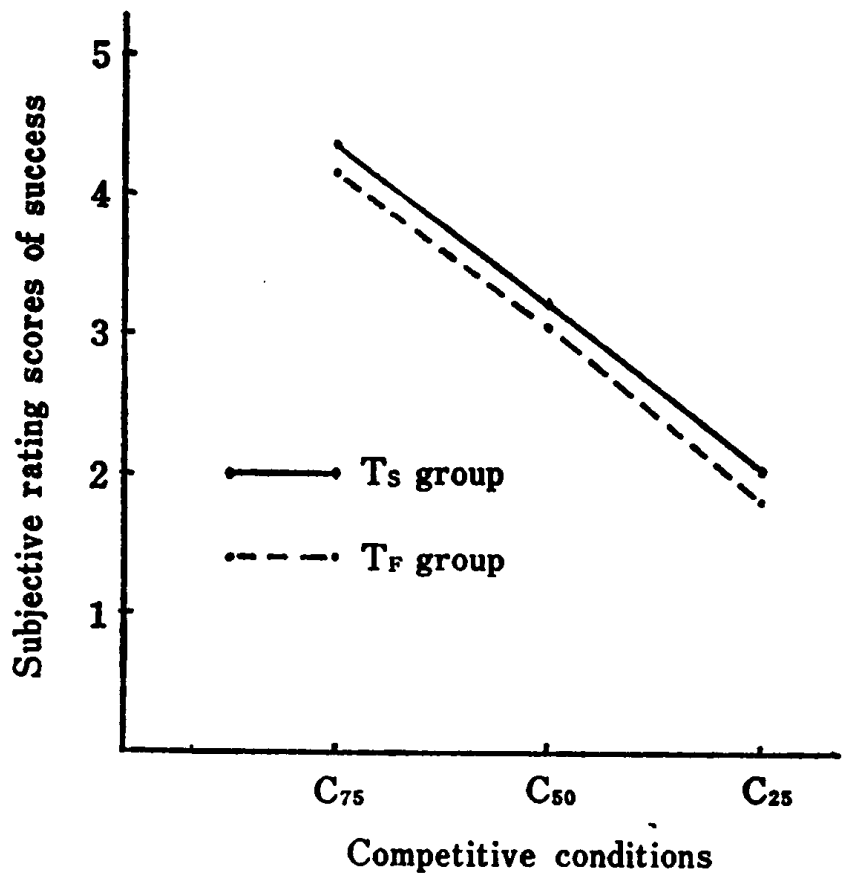

Fig. 3. Mean subjective rating scores of success under three competitive conditions on the zigzag run task $\mathrm{C}_{73}$...Competition with inferior ability opponents $\mathrm{C}_{30}$... Competition with equal ability opponents $\mathrm{C}_{23}$... Competition with superior ability opponents 


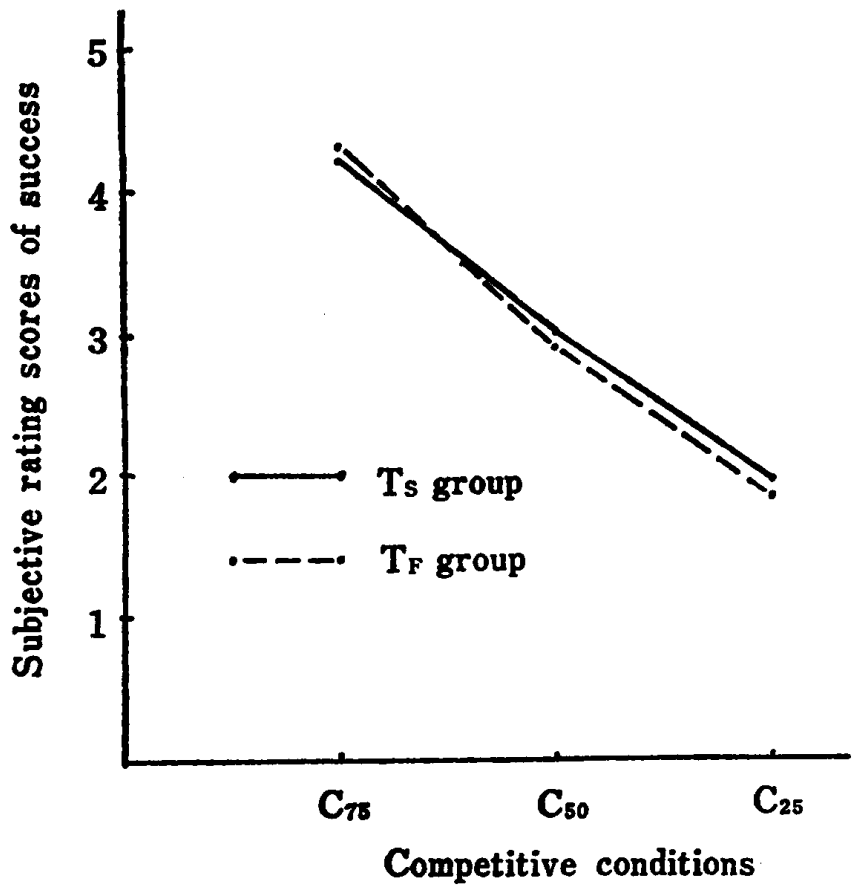

Fig 4. Mean subjective rating scores of success under three competitive conditions on the serial jumping taesk

た，報告された評定点の 1 回目と 2 回目の相関係 数は, ジグザグランで0.89, ケンケンとびで 0.84 を示し 2 回ともかなり恒常的であった。

これらの結果から，被験者は異なる競争条件下 で課題を遂行していたことが認められ，実験者が 設定した競争条件は，被験者が報告した主観的評 定点とほぼ対态していたと考えられる。

$<2>$ 仮説㭘証に関する結果

統制条件および 競争条件におけるジグザグラ ン，ケンケンとび 得点の各群の平均と標準偏差を
Table. 1，3，に示した.ここで，統制条件でのケ ンケンとび得点において, $T_{\mathrm{B}}$ 群が $\mathrm{T}_{\mathrm{F}}$ 群よりも有 意に高い得点 $(p<.001)$ を示したことは， $T_{8}$ 群 が $\mathrm{T}_{\mathrm{F}}$ 群よりも高能力群であることを意味してお り，競争条件への変化量が群よりす少なくなる ことが予想される・そこで，能力差をコントロー ルするために，競争条件の統制条件への回帰係数 を考慮して，両課題についてそれぞれ達成動機 (2) $\times$ 競争条件 (4)の 2 要因共分散分析を行なっ た。（Tab. 4.5）また，各競争条件の調整平均傎 を(Fig. 5.6) に示した。

その結果, ジグザグラン，ケンケンとびとも達 成動機，競争条件の要因に有意差がみられ，雨課 題とも達成動機の高低および競争相手に対する勝 敗の主観的な認知によって，競争の効果が異なそ， ことが示された。

そこで，ジグザグランにおける達成動機の競争 条件差を検定した結果，Ts群では，N.C条件より む) $\mathrm{C}_{50}, \mathrm{C}_{25}$ 条件の方が有意に高いパフォーマンス を示した。（いずれも $\mathrm{p}<.01 ）$ また， $\mathrm{C}_{50}$ 条件は， $\mathrm{C}_{75}$ 条件よりも有意に高いパフォーマンスをご, た. $(\mathrm{p}<.05)$ 一方, TP群であ, N.C条件よ门的 $\mathrm{C}_{73}, \mathrm{C}_{50}, \mathrm{C}_{25}$ 条件の方が有意に高いパフォーマソ

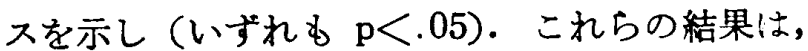
仮説 1 を支持するものであった。

仮説 2 に関して，ジグザグランにおける競争条 件の達成動機差を検定した結果， $\mathrm{T}_{\mathrm{S}}$ 群の方が $\mathrm{T}_{\mathrm{F}}$ 群 よりも有意に高いパフォーマンスを示したのは， $\mathrm{C}_{30}$ 条件 $(\mathrm{p}<.01)$ だけで，仮説 2 を必ずしも支

Tab. 3 Mean performances and standard deviation under competitive conditions

(points)

\begin{tabular}{|c|c|c|c|c|c|c|c|c|c|}
\hline \multirow{2}{*}{\multicolumn{2}{|c|}{ Grou p }} & \multicolumn{4}{|c|}{ The zigzag run task } & \multicolumn{4}{|c|}{ The serial jumping task } \\
\hline & & N.C & $\mathrm{C}_{73}$ & $\mathrm{C}_{30}$ & $\mathrm{C}_{25}$ & N.C & $\mathrm{C}_{75}$ & $\mathrm{C}_{30}$ & $\mathrm{C}_{25}$ \\
\hline \multirow{3}{*}{$T_{s}$} & $\mathbf{N}$ & 19 & 19 & 19 & 19 & 19 & 19 & 19 & 19 \\
\hline & $\mathbf{M}$ & 92.18 & 94.24 & 98.64 & 96.93 & 24.53 & 23.79 & 25.42 & 26.05 \\
\hline & S.D & 4. 85 & 5.02 & 4. 58 & 6.48 & 4.50 & 4. 84 & 4. 95 & 5.22 \\
\hline \multirow{3}{*}{$T_{F}$} & $\mathbf{N}$ & 19 & 19 & 19 & 19 & 19 & 19 & 19 & 19 \\
\hline & $\mathbf{M}$ & 90.58 & 95.00 & 93.71 & 95.28 & 20.05 & 20.00 & 17.00 & 17.95 \\
\hline & S.D & 6.90 & 5.75 & 3.75 & 5.74 & 5.39 & 5.37 & 4.95 & 4.83 \\
\hline
\end{tabular}


Tab. 4 Analysis of covariance (The zigzag run task)

\begin{tabular}{c|r|r|r|c}
\hline Source & $\mathrm{SS}^{\prime} \mathbf{Y}$ & $\mathrm{df}$ & $\mathrm{MS}^{\prime}$ & $\mathrm{F}$ \\
\hline $\begin{array}{c}\text { Achievement } \\
\text { motivation } \\
\begin{array}{c}\text { Competitive } \\
\text { conditions }\end{array} \\
\text { Error }\end{array}$ & 56.03 & 1 & 56.03 & $4.55^{*}$ \\
\hline Total & 1796.67 & 146 & 12.31 & \\
\hline & 2311.74 & 150 & & \\
\hline
\end{tabular}

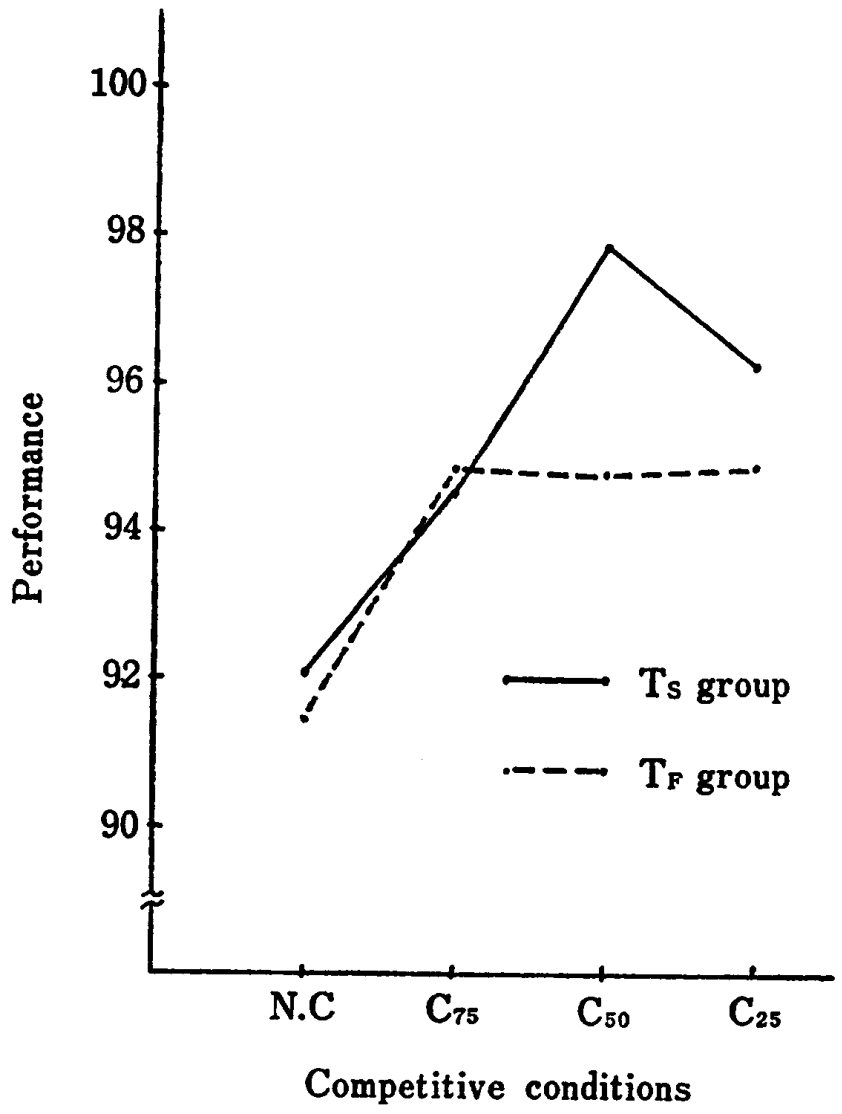

Fig. 5. Mean performances adjusted by regression coefficient of competitive conditions on control condition (The zigzag run task)

N. C...noncompetition

$\mathrm{C}_{75} \cdots$ competition with inferior ability opponents $\mathrm{C}_{30}$ \%competition with equal ability opponents

$\mathrm{C}_{25} \cdots$ competition with superior ability opponents

持する結果ではなかった。

次に，ケンケンとびにおける達成動機の競争条 件差を検定した結果， $\mathrm{T}_{\mathbf{s}}$ 群では競争条件間に有意 差がみられなかったが, T群ではN.C， C $75, C_{25}$ 条件と比較して， $\mathrm{C}_{50}$ 条件は有意に低いパフォー

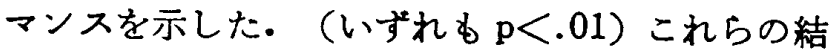

Tab. 5 Analysis of covariance (The serial jumping task)

\begin{tabular}{c|r|r|r|c}
\hline Source & SS $^{\prime} \mathbf{y}$ & df & MS $^{\prime}$ & F \\
\hline Achievement motivation & 143.95 & 1 & 143.95 & $40.89^{* *}$ \\
Competitive conditions & 36.69 & 3 & 12.23 & $3.47^{*}$ \\
Error & 514.10 & 146 & 3.52 & \\
\hline Total & 694.74 & 150 & & \\
\hline & ${ }^{* *} \mathrm{P}<.01$ & \\
\hline
\end{tabular}

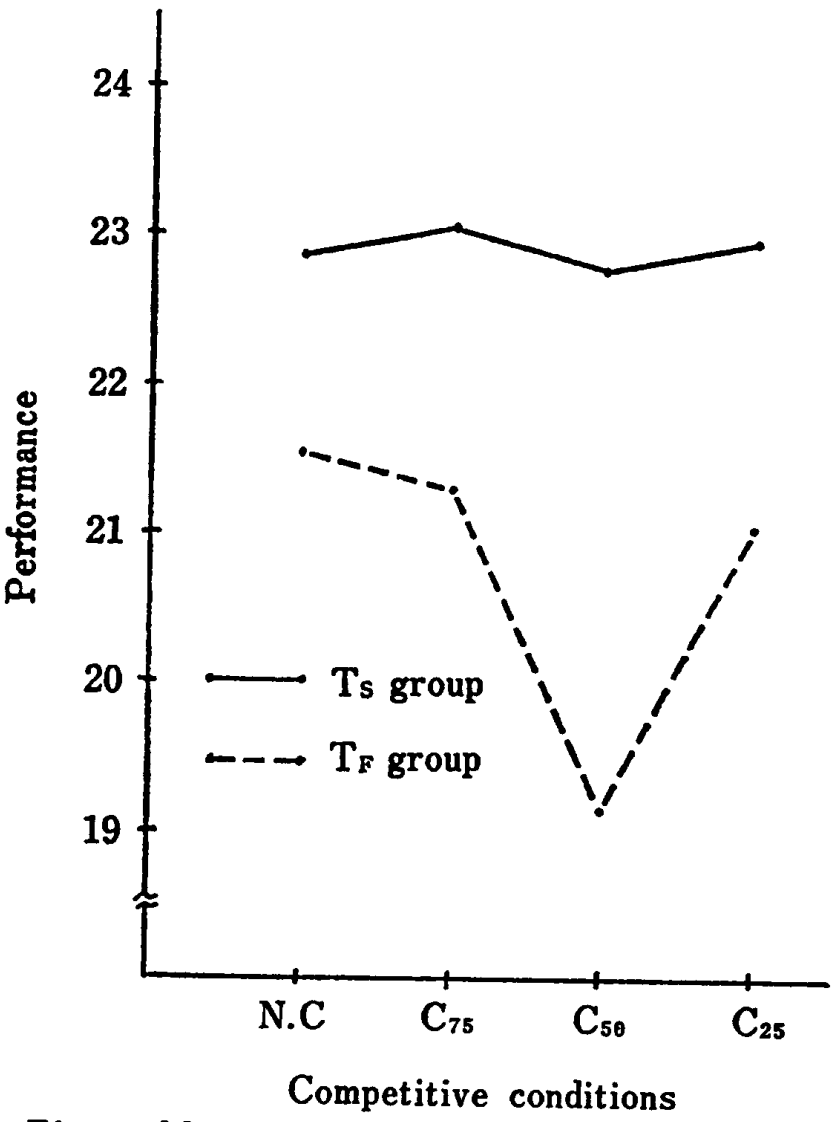

Fig. 6. Mean performances adjusted by regression coefficient of competitive conditions on control condition (The serial jumping task)

果は，T群に関しては仮説 3 を支持するすのであ った。

仮説 4 K関して，ケンケンとびにおける競争条 件の達成動機差を検定した結果，全ての競争条件 において， $\mathrm{T}_{\mathrm{F}}$ 群の方が $\mathrm{T}_{\mathrm{s}}$ 群よりも有意に低いハ フォーマンスを示した．（N.C 条件‥p $<.05 ， C_{75}$ 条件 $\cdots \mathrm{p}<.01, \mathrm{C}_{50}$ 条件 $\cdots \mathrm{p}<.001, \mathrm{C}_{25}$ 条件 $\cdots \mathrm{p}<$ .01）これらの結果は，仮説 4 を支持するもので あった。 
以上の結果は，本研究の仮説をほぼ支持するも のと考兄られる.そこで，次のように要的するこ とができるであろ5。

ジグザグランでは，Ts 群，T群とも， N.C条 件よりも競争による有意に高いパフォーマンスが みられ，その傾向は特に $\mathrm{C}_{30}$ 条件で著しく促進さ れた。また， $\mathrm{T}_{\mathrm{s}}$ 群と $\mathrm{T}_{\mathrm{F}}$ 群を比較すると， $\mathrm{C}_{30}$ 条件 でTs群の方が有意に高いパフォーマンスがみられ た。

ケンケンとびでは，T群は競争によるパフォー マンスの有意な変化はみられなかったが，T群は $\mathrm{C}_{30}$ 条件において，N.C， $\mathrm{C}_{75} ， \mathrm{C}_{25}$ 条件よりも有意 に低いパフォーマンスがみられた。また，T群と T下群を比较すると，どの競争条件においても， $\mathrm{T}_{\mathrm{F}}$ 群は $\mathrm{T}_{\mathrm{B}}$ 群よりあ有意に低いパフォーマンスが みられた。

\section{[5]考察}

本研究は, 競争の効果をより明確に把握するた めに, J. W. Atkinson の「期待一誘因価モデル」 と Yerkes-Dodson の法則から導びかれた仮説 を，運動パフォーマンスに焦点をあてて検討する ことを主な目的とした。そして，これらの仮説 は，次のよ5な理由でほぼ支持される方向にあっ たと考えられる。

まず，仮説 1 に関して，ジグザグランでT $\mathrm{s}$ 群， T群とも競争による有意なパフォーマンスの增加 がみられ，特に $\mathrm{C}_{30}$ 条件でその最大を示したとい 弓結果は，J. W. Atkinson の「期待一誘因価モ デル」と Yerkes-Dodson の法則から説明するこ とができるつっまり，主としてスピードを要求す るジグザグランは，動機づけが強くなればなるは どパフォーマンスが增大すると考学られるからで ある・またこれらの結果は，競争によってパフ オーマンスの量が增大したという I. C. Whittemore, (192426) や, M. E. Shaw, (195823) $)$, E. Rudow, and J. Hautaluoma $\left(1975^{20}\right)$ の研究 結果と一致している.

しかし，仮説 2 に関しては，ジグザグランで,

Ts 群は T 群よりる競争を導入することによっ て，バフォーマンスがより促進されるであろ5と 予測したのであるが，両群に有意差がみられたの は $\mathrm{C}_{50}$ 条件だけであった。このことは，本研究で
用いたジグザグランが，被験者にとってあまりに 単純で容易な課題であったために，たとえ課題に 対して回避傾向を持つT群であっても，不安動機 （失敗回避動機）が強く喚起されず，両群のパフ ォーマンスに差が生じなかったのではないかと思 われる。

仮説 3 に関して，ケンケンとびで，Ts群に競争 によるパフォーマンスの有意な堿少がみられなか った・これは，競争という強い動機つけが導入さ れても，主として鋭敏な知党判断や協応性を必要 とするいわゆる複雑で困難な課題が要 求される と，競争相手を意識できなくなり自分の枠組みの 中で課題を遂行したからと思われる。つまり， $\mathrm{T}_{\mathrm{s}}$ 群は課題を遂行しようという接近の傾向はある が，課題があまりに複雑で困難なために競争が動 機つけとしての機能を持たず，パフォーマンスに 変化が生じなかったのではないたろうか。しか し，この点に関しては, T $\mathrm{s}$ 群の行動特性をより明 確に把握するためにも, 今後さらに検討する必要 があると思われる，一方，Tr群に競争による有意 なパフォーマンスの娍少が $\mathrm{C}_{30}$ 条件でみられたの は， T群は競争という強い動機つけ場面に立たさ れた5党，複雑で困難な課題を遂行するよ5教示 されると，不安動機(失敗回避動機) が強く唤起 されるとともに誤反応が增大したために，パフォ 一マンスが減少したと考觉られる・このような競 争による不安動機（失敗回避動機）の喚起に伴な 5パフォーマンスの減少は, ケンケンとび得点と T.A.S.C. 得点の変化量に, 有意な負の相関が得ら れたとい5予備実験の結果からも推察できること である.また，課題に対する回避への動機づけが 最大になる $\mathrm{C}_{30}$ 条件で著しいパフォーマンスの娍 少がみられたのは，J. W. Atkinson の「期待一 誘因価モデル」をよく支持している結果である.

仮説 4 に関して，ケンケンとびで， $\mathrm{T}_{\mathrm{F}}$ 群が $\mathrm{T}_{\mathrm{s}}$ 群よりも競争によってパフォーマンスがより抑制 されたのは，前述のように $\mathrm{T}$ 群に强い不安動機 （失敗回避動機）が喚起されたためであろ5と思 われる.

次火， $\mathrm{T}_{\mathrm{s}}$ 群， $\mathrm{T}_{\mathrm{Y}}$ 群の行動特性からパフォーマ ンスに着目してみると，本研究において，ジグザ ジランでは両群にパフォーマンスの有意な差はみ 
られなかったがケンケンとびになると両群に有 意な差がみられた。このことは，T群が知的な課 題を達成しょうとする傾向が强く，知能や学業成 絰と正の相関があることや，行動の結果が自分の 能力や努力に帰因する 比較的解決困難な課題を好 む傾向が強いのに刘して，T群はそのよ5な課題 で失敗することを恐れる傾向が強いためだと考え られる・また，ケンケンとびに拈いて，Ts群は， 「もっとやってみたい」「今度はいい成結をとっ てやる」とい5内省埌告が多くみられたのに対し て，T群は，「す5やたくない」「人に見られ ているのでいやだ」とい5内省報告を示したこと からも,このような結果が得られたのではないか と思われる。

以上考察してきたことから，競争場面におい て，達成動機および失敗回避動機とい5性格特性 が運動パフォーマンスに大きく関与し，さらに競 争相手に対する勝敗の主観的な認知によっても影 帮をらけることが認められた。

しかし，本研究の結果は，競争行動が旺盛であ ると思われる小学校. 5 年生男子においてである. それでは，表面的な競争行動が内面化してくる青 年期の学生や生徒にも, 本研究の結果のようなこ とが言えるのであろうかまま，逢成動機や競争 行動は，その発生メカニズムや形成過程が重要で あることを考学ると，組織的で緃断的な研究が望 まれる。

さらに, M.S. Hornor, (1968 $\left.{ }^{11}\right)$ によると, 成 人女性には達成志向場面 での成功への不安（fear of success)，つまり，知的に達成することが女ら しさを失ない，同時に社会的に拒否されるのでは ないかとい5不安があると言われている。これ は，性役割行動にあ関係することであるが，この 不安が競争場面での運勳パフォーマンスにどのよ らな影翼を及ぼすのか，さらに検討の余地があろ 5 .

なお，本研究は，1976年度，東京教育大学体青学部 飞提出された修士詥文の一部をまとめたすのである。 論文の完成にあたり御指尊いただいた，筑波大学の松 田岩男，加贺秀夫，市村操一，杉原隆の各先生方飞対 して，また，本研究の泪定まよび実跉に際して，御協 カいただいた小学校の睹先生方に対して，おらためて 原く惑剧致します。

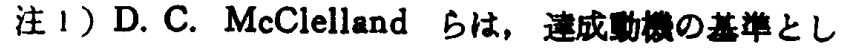
て，(1)卓越基蒴を設定し，これイ挑むこと，(2)独自な やり方て连成しようとすること，(3)長期間かかる造成 を期していること，をあけている。なお，具体的な琛 点方法は文献14を厺煦されたい。

注 2 ）探点飞あたり，大阪大学の岡崎和子氏の協力を得 ז.

注 3) AI の一致事=

$$
\frac{2 \times 0 \text { 氏 } \cdot \mathrm{N} \text { 氏のAI の一数 }}{\text { O氏のAIの数+N氏のAIの数 }} \times 100
$$

\section{考文 献}

1) Atkinson, J. W. and Reitman, W.R. Performance as a function of motive strength and expectancy of goal-attainment. J. Abnorm. Soc. Psychol., 53, 361 66, 1956.

2) Atkinson, J.W. Motivational determinants of risk-taking behavior. Psychol. Rev., 64, 359 72, 1957.

3) Atkinson, J. W. Motives in fantasy, action and society., Van Nostrand, 1958.

4) Atkinson, J.W., Bastian, J.R., Earl, R.W. and Litwin, G.H. The achievement motivation, goal setting and probability preferences. J. Abnorm. Soc. Psychol., 60, 27 36, 1960.

5 ) Atkinson, J. W. and Litwin, G. H. Achievement motive and test anxiety conceived as motive to approach success and motive to avoid failure. J. Abnorm. Soc. Psychol., 60, 52 63, 1960.

6) Atkinson, J.W. and O'Connor, P. Neglected factors in studies of achievement-oriented performance : Social approach as incentive and performance decrement. In Atkinson, J.W. and Feather, N.T. (Eds) A theory of achievement motivation., John Wiley, 299 325, 1966.

7) Church, R.M. The effects of competition on reaction time and palmar skin conductance. $J$. Abnorm. Soc. Psychol., 65, 32 40, 1962.

8) Feather, N. T. Performance at a difficult task in relation to initial expection of success and test anxiety and need achievement. J. Pers., 33, 200 17, 1965.

9) French, E.G. and Thomas, F.H. The relation of achievement motivation to problemsolving 
effectiveness. J. Abnorm. Soc. Psychol., 56, 45 $\sim 48,1958$.

10) Healey, T. R. and Landers, D.M. Effect of need achievement and task difficulty on competitive and noncompetitive motor performance. J. Motor Behav., 5, 121 28, 1973.

11) Hornor, M.S. Sex differences in achievement motivation and performance in competitive and non-competitive situations. Unpublished doctoral dissertation, University of Michigan, 1968.

12) Karabenick, S.A. and Youssef, Z.I. Performance as function of achievement motive level and perceived difficulty. J. Pers. Soc. Psychol., $10,414 \sim 19,1968$.

13）松井三堆 : 体青心理学, pp. 188～92. 体育の科学 社, 1971 .

14) McClelland, D. C., Atkinson, J. W., Clark, R.A. and Lowell, E. L. The achievement motive., Appleton-Century, 107 38, 1953.

15）长田一臣：体育心理学, pp. 127 30. 道和害院, 1969.

16) Raynor, J. O. and Smith, C.P. Achievement related motives and risk-taking in games of skill and chance. J.Pers., 34, 176 98, 1966.

17) Raynor, J.O. and Rubin, I.S. Effects of achievement motivation and future orientation on level of performance. J. Pers. Soc. Psychol., 17, $36 \sim 41,1971$.

18) Roberts, G.C. Effect of achievement motivation and social environment on performance of a motor task. J. Motor Behav., 4, 37 46, 1972.

19) Roberts, G.C. Effect of achievement motivation and social environment on risk-taking. Res. Quart., 45, 42 55, 1974.

20) Rudow, E. and Hautaluoma, J. Competition with oneself versus others as a facilitator in the classroom. J.Soc. Psychol., 95, 281 $82,1975$.

21) Ryan, E.D. and Lakie, W.L. Competitive and noncompetitive performance in relation to achievement motive and manifest anxiety. J. Pers. Soc. Psychol., !, 342 45, 1965.

22) Sarason, S.B., Lighthall, F.F., Davidson, K.S., Waite, R. R. and Ruebush, B.K. Anxiety in elementary school children., Jhon Wiley, 306 $09,1960$.

23) Shaw, M.E. Some motivational factors in cooperation and competition. J. Pers., 26, 155 $69,1958$.

24) Strong, C.H. Motivation related to performance of physical fitness tests. Res. Quart., 34, 497 507, 1963.

25）右高尚美：「Motivation としての競争が児童生徒 に与える影靁について」末利 博・体育心理(上), pp. 190〜91, 运遥書院, 1969 より引用.

26) Whittemore, I.C. The influence of competition on performance : An experimental study. J. Abnorm. Soc. Psychol., 19, 236 53, 1924. 